\title{
Analisa Tren Untuk Memprediksi Perubahan Kriteria Keunagan Pada Indeks Shariah
}

\author{
Ika Widiastuti $^{1)}$, dan Pandu Adi Cakranegara ${ }^{2)}$ \\ ${ }^{1}$ Jurusan Administrasi Negara, Universitas Krisnadwipayana \\ ${ }^{2}$ Program Studi, Universitas Presiden \\ $1,2,3$ alamat, kota, kodepos \\ e-mail: ikawidiastuti86@gmail.com ${ }^{1}$,pandu.cakranegara@president.ac.id ${ }^{2}$
}

Received: 13 August 2021; Revised: 02 October 2021; Accepted: 14 December 2021

DOI: http://dx.doi.org/10.37905/aksara.8.1.461-470.2022

\begin{abstract}
Abstrak
Untuk memfasilitasi investor yang memegang nilai-nilai shariah maka dibentuklah indeks shariah di Bursa Efek Indonesia. Bursa Shariah ini memiliki syarat-syarat khusus berdasar prinsip shariah dalam menjalankan usahanya. Syarat-syarat khusus ini terdiri dari syarat kualitatif dan kuantitatif. Syarat kualitatif adalah perusahaan tidak menjual barang yang tidak halal dan dalam usahanya perusahaan tidak melakukan hal-hal yang tidak halal. Syarat kuantitatif adalah syarat operasional perusahaan yang tercermin dari bagaimana perusahaan menggunakan pendanaan dan meminjamkan dana. Di dalam bursa efek, terdapat indeks syariah yang berisi perusahaan-perusahaan yang beroperasi dengan prinsip shariah. Indeks ini tidak bersifat tetap dan selalu diperbaharui. Ketika perusahaan melakukan hal yang tidak halal atau mengalami perubahan secara operasional. Apabila perusahaan secara operasional berubah dan tidak memenuhi syarat maka perusahaan tersebut dikeluarkan dari daftar efek syariah. Konsekuensinya adalah investor yang memegang saham yang keluar dari indeks shariah maka perlu melepas saham tersebut dari portofolionya. Alokasi portofolio yang ideal adalah alokasi portofolio yang direncanakan sehingga dengan mengetahui lebih dahulu dari perubahan kehalalan suatu saham. Salah satu metode yang dapat digunakan untuk melihat arah operasional saham adalah dengan analisa tren. Penelitian ini memanfaatkan analisa tren. Dengan menggunakan data historis penelitian ini menunjukkan bahwa analisa tren sebenarnya telah menunjukkan arah pergerakan operasional suatu saham dan risiko suatu saham. Saham yang berisiko cenderung memiliki potensi akan dikeluarkan pada periode berikutnya.
\end{abstract}

Kata Kunci: indeks shariah, pendanaan, analisa tren

\section{PENDAHULUAN}

Indonesia sebagai negara muslim terbesar di Indonesia memiliki basis investor muslim yang besar. Namun yang menjadi tantangan adalah para investor ini terkait dengan nilai-nilai religius yang melarang untuk berinvestasi di usaha-usaha yang memiliki unsur riba di dalamnya. Salah satu solusi yang diberikan oleh pihak bursa untuk memfasilitasi hal ini adalah dengan menunjuk sebuah dewan syariah. Selanjutnya dewan syariah ini akan mengeluarkan daftar perusahaan-perusahaan yang memenuhi syarat sebagai perusahaan yang tidak memiliki unsur riba.

Dewan syariah menggunakan dua kriteria utama dalam menyaring perusahaan untuk dapat dikategorikan sebagai sebuah perusahaan yang dapat masuk daftar syariah. Kriteria pertama adalah kriteria bisnis dan kriteria kedua adalah kriteria keuangan. Kriteria pertama merupakan kriteria yang secara khusus menyaring perusahaan secara bisnis. Kriteria tersebut terdiri dari: Perusahaan tidak terlibat dalam kegiatan perjudian, Perusahaan tidak memperdagangkan barang dan jasa yang dilarang, Tidak memiliki operasi jasa keuangan ribawi, Jual beli risiko yang mengandung unsur ketidakpastian 
(gharar), Perusahaan tidak memproduksi atau mendistribusi barang haram, Perusahaan tidak terlibat suap

Kriteria kedua adalah kriteria keuangan. Kriteria ini bersifat menyaring perusahaan dari sisi keuangan. Dari sisi keuangan terdapat dua sisi yang secara khusus dilihat oleh dewan syariah. Sisi pertama adalah sisi pendanaan. Sebuah efek yang dikategorikan syariah tidak boleh didanai lebih dari empat puluh lima persen dengan bunga yang bersifat riba. Sisi kedua adalah sisi pendapatan. Ketika sebuah efek memiliki lebih dari sepuluh persen pendapatan berasal dari bunga yang bersifat riba maka efek tersebut tidak dapat dimasukkan ke efek syariah (Romi Gunawan, 2021).

Kriteria pertama merupakan kriteria yang bersifat kualitatif dan bersifat biner. Artinya sebuah efek akan dikategorikan menjadi dua yaitu efek yang memenuhi kriteria atau efek yang tidak memenuhi kriteria. Kelima kriteria yang ada dalam kriteria bisnis bersifat mutlak. Artinya jika sebuah efek tidak memenuhi salah satu syarat maka efek tersebut tidak dapat dikategorikan ke efek syariah. Atau dengan kata lain agar sebuah efek dapat memenuhi syarat di kriteria bisnis maka efek tersebut harus memenuhi semua kriteria.

Kriteria kedua merupakan kriteria kuantitatif di mana kriteria ditetapkan dengan menggunakan batasan sebuah angka persentase. Angka persentase yang ditetapkan oleh dewan syariah merupakan batasan yang dapat ditoleransi. Kriteria keuangan juga merupakan kriteria yang seluruhnya wajib dipenuhi. Jadi jika salah satu kriteria dalam kriteria keuangan tidak terpenuhi maka efek tersebut tidak dapat masuk ke dalam daftar syariah.

Secara total maka ada delapan kriteria yang harus dipenuhi. Enam kriteria merupakan kriteria bisnis dan dua merupakan kriteria keuangan. Ini adalah tujuh kriteria penyaringan yang akan menyaring sebuah perusahaan guna memastikan agar perusahaan tersebut dijalankan berdasar prinsip syariah (Hartati, 2021). Kemudian perusahaan yang tersaring akan dimasukkan ke dalam Daftar Efek Syariah dan kemudian diumumkan ke publik oleh Dewan Syariah.

Jika sebuah perusahaan sudah masuk ke dalam Daftar Efek Syariah pada suatu periode bukan berarti perusahaan tersebut akan masuk ke dalam daftar pada periode berikutnya. Hal itu tergantung dari kemampuan perusahaan untuk berpegang teguh pada prinsip syariah. Jadi misalnya secara bisnis perusahaan terlibat suap baik yang dilakukan secara sistematis maupun dilakukan oleh oknum yang berkuasa di perusahaan tersebut maka perusahaan akan dikeluarkan dari daftar.

Secara kriteria keuangan perusahaan bisa jadi terpental dari Daftar Efek Syariah karena pendanaannya lebih dari empat puluh lima persen dengan menggunakan pendanaan riba. Hal ini dapat terjadi jika perusahaan misalnya saat ini memiliki pendanaan riba sebesar empat puluh persen yang secara kriteria keuangan masih dapat ditoleransi, namun ketika nilai pasar utang naik sehingga proporsi pendanaan riba menjadi di atas empat puluh lima persen maka perusahaan akan melanggar kriteria. Konsekuensinya perusahaan akan dikeluarkan dari Daftar Efek Syariah.

Pada kriteria pertama yang terkait dengan kriteria bisnis maka perusahaan dapat terdepak karena perilaku perusahaan tidak sesuai dengan prinsip syariah. Untuk menjaga agar jangan sampai ada kriteria pertama yang dilanggar maka ini merupakan tanggung jawab perusahaan untuk menjaga etika dan integritas dalam berbisnis. Namun kriteria keuangan tidak sepenuhnya terkait dengan kriteria etika dan integritas 
perusahaan. Pada kriteria kedua ada faktor pasar yang mempengaruhi kondisi keuangan perusahaan. Ketika kondisi makroekonomi berubah atau tingkat suku bunga naik yang mempengaruhi nilai pinjaman atau pendapatan riba perusahaan maka ini dapat menyebabkan perusahaan melanggar kriteria yang telah ditetapkan.

Dari sisi investor, penting untuk mengetahui bahwa perusahaan yang semula syariah bisa jadi pada periode berikutnya sudah tidak lagi memenuhi kriteria syariah sehingga tidak dapat lagi dimasukkan ke dalam lingkup investasinya. Untuk dapat memprediksi ini maka salah satu cara yang dapat digunakan investor adalah dengan meramal bagaimana perubahan yang kira-kira akan terjadi pada kriteria keuangan. Perubahan yang terjadi pada kriteria keuangan terkait dengan perubahan pada kondisi industri terutama industri keuangan.

Tujuan dari penelitian ini adalah untuk menganalisa perusahaan mana yang akan keluar dari daftar efek shariah. Penelitian ini secara khusus menggunakan analisa tren. Harapannya dengan melakukan analisa terlebih dahulu investor dapat lebih siap untuk mengelola portofolionya.

Bagi investor yang memeganng prinsip shariah maka terdapat hal lain yang perlu dijaga dalam berinvestasi selain imbal balik. Ketika sebuah saham tidak lagi di dalam daftar indeks shariah maka saham tersebut tidak dapat masuk ke dalam semesta portofolionya. Konsekuensinya adalah saham tersebut perlu dikeluarkan dari portofolio. Dan jika investor ingin seluruh dananya diinvestasikan secara penuh maka saham yang dijual tersebut perlu diganti dengan saham yang sesuai dengan portofolio investor.

Jika investor tidak siap dengan perubahan yang terjadi maka investor tidak dapat melakukan alokasi saham di portofolio dengan baik. Untuk menciptakan sebuah portofolio yang baik diperlukan perencanaan dan melihat kondisi pasar untuk mengetahui waktu yang tepat untuk berinvestasi dan menjual investasi.

Dengan mengetahui tren saham maka investor dapat lebih siap dalam mengelola portofolionya. Harapannya adalah dengan mengetahui saham-saham yang berpotensi untuk dikeluarkan dari daftar indeks shariah maka investor dapat lebih siap dalam pengelolaan investasinya.

Hasil yang diharapkan dari penelitian ini adalah suatu kerangka untuk menganalisa tren yang kelak dapat digunakan menjadi salah satu pertimbangan untuk menganalisa perusahaan yang berpotensi keluar dari daftar indeks shariah.

\section{METODE PENELITIAN}

Penelitian ini merupakan penelitian kuantitatif. Artinya penelitian ini menggunakan data yang berupa angka dan menggunakan metode statistik dalam pengolahannya. Data yang digunakan adalah data sekunder yaitu data yang berasal dari sumber kedua. Data diambil dari laporan keuangan perusahaan. Laporan keuangan idealnya memiliki opini wajar tanpa pengecualian yang merupakan laporan opini audit tertinggi. Namun karena perusahaan yang dipilih adalah perusahaan di dalam Daftar Efek Syariah maka aman untuk menyatakan bahwa secara bisnis perusahaan telah bertindak seusai etika.

Metode statistik yang digunakan adalah metode analisa tren. Metode ini metode peramalan sederhana dengan melihat data secara urut waktu. Dari data tersebut kemudian ditarik suatu nilai rata-rata dengan asumsi bahwa nilai ini akan bertahan ke depannya. Metode rata-rata yang digunakan adalah menggunakan metode aritmetika. Metode aritmetika dipilih karena menghasilkan rata dengan nilai tertinggi dibandingkan 
metode rata-rata geometrik. Dengan memberikan nilai yang tertinggi akan menghasilkan nilai tren yang paling tinggi. Ini akan menghasilkan perkiraan yang paling konservatif terhadap perubahan yang mungkin terjadi pada nilai yang dihasilkan.

Metode analisa tren atau metode urut waktu merupakan salah satu metode yang digunakan dalam ilmu keuangan untuk melakukan peramalan. Dalam penelitian ini adalah peramalan nilai saham. Metode urut waktu meramal nilai masa depan masa depan suatu saham bukan dari faktor-faktor yang mempengaruhi saham tersebut melainkan dari nilai masa lalu variabel tersebut. Asumsi peramalan variabel dengan analisa tren adalah perilaku variabel akan terus berlanjut dan perilaku variabel di masa depan terpengaruh oleh perilaku variabel di masa lampau.

Piranti lunak yang digunakan untuk melakukan analisa peramalan adalah Microsoft Excel. Pemilihan Microsoft Excel dikarenakan piranti lunak ini tersedia luas terutama di kalangan bisnis di Indonesia. Selain itu dengan menggunakan Excel dapat dibuat kertas kerja yang terdari dari beberapa kertas kerja sekaligus. Sehingga setiap variabel dapat ditelusur mulai dari data hingga langkah demi langkah proses peramalan.

Tujuan dari penelitian ini adalah meramalkan nilai dari utang dan pendapatan perusahaan yang berasal dari dana riba. Oleh karena itu akan ada dua analisa tren. Kedua analisa tren ini merupakan model yang terpisah. Masing-masing dari model akan dianalisis tren ke depannya. Setelah dihasilkan angka peramalan yang menunjukkan nilai perkiraan dari utang dan pendapatan perusahaan maka kemudian nilai ini dibandingkan dengan kriteria yang ditetapkan oleh Dewan Syariah. Ketika nilai yang diramalkan melebihi batas maksimal yang ditentukan oleh Dewan Syariah maka perusahaan tersebut kemungkinan akan keluar dari Daftar Efek Syariah yang selanjutnya.

\section{HASIL DAN PEMBAHASAN}

Penelitian ini terdiri dari langkah-langkah pada diagram 1. Langkah pertama adalah pengumpulan data yang dilakukan secara manual dari laporan keuangan. Data yang diambil ini adalah empat jenis data. Dua data berasal dari neraca dan dua data lainnya berasal laporan laba rugi. Data yang berasal dari neraca adalah aset dan liabilitas berbunga. Data yang berasal dari laba rugi adalah pendapatan penjualan atau total pendapatan dan pendapatan non halal (Baining \& Aryani, 2021).

Data yang diambil adalah data per kuartal yang berasal dari laporan interim perusahaan. Penggunaan data per kuartal ini untuk menyesuaikan siklus bisnis yang bersifat jangka pendek. Sementara itu penggunaan data yang lebih jangka panjang memiliki keunggulan untuk memberikan informasi yang lebih lengkap tentang performa keuangan perusahaan. Namun di sisi lain data yang diambil akan terpengaruh oleh siklus ekonomi. Dengan berfokus pada set data yang lebih pendek maka analisa yang dihasilkan berdasarkan performa perusahaan pada siklus bisnis terkini.

Langkah selanjutnya adalah memproses data dengan menggunakan kertas kerja di piranti lunak Microsoft Excel. Data di masukkan ke dalam kertas kerja per kuartal untuk melihat perubahannya dari tahun-tahun. Pendekatan aritmetika mengikut sertakan perbuahan dari tahun ke tahun sehingga hasil rata-rata yang ada mencerminkan volatilitas dari tahun ke tahun. 


\begin{tabular}{|c|c|c|}
\hline $\begin{array}{l}\text { Bahan } \\
\text { baku }\end{array}$ & $\begin{array}{l}\text { Laporan } \\
\text { Keuangan }\end{array}$ & $\begin{array}{l}\text { Data } \\
\text { pendapatan, } \\
\text { pendapatan } \\
\text { bunga, aset, } \\
\text { liabilitas }\end{array}$ \\
\hline \multirow{2}{*}{ Proses } & $\begin{array}{l}\text { Menghitung } \\
\text { perubahan } \\
\text { tahunan }\end{array}$ & $\begin{array}{l}\text { Menghitung } \\
\text { perubahan } \\
\text { dari tahun ke } \\
\text { tahun }\end{array}$ \\
\hline & $\begin{array}{l}\text { Menghitung } \\
\text { tren }\end{array}$ & $\begin{array}{l}\text { Menghitung } \\
\text { tren } \\
\text { pertumbuhan }\end{array}$ \\
\hline Output & $\begin{array}{l}\text { Peramalan } \\
\text { pendapatan, } \\
\text { pendapatan } \\
\text { bunga, aset } \\
\text { dan } \\
\text { liabilitas }\end{array}$ & $\begin{array}{l}\text { Output } \\
\text { Kriteria } \\
\text { Keuangan } 1 \\
\text { dan Kriteria } \\
\text { Keuangan 2 } \\
\end{array}$ \\
\hline Analisa & $\begin{array}{l}\text { Tetap atau } \\
\text { keluar dari } \\
\text { Daftar Efek } \\
\text { Syariah }\end{array}$ & $\begin{array}{l}\text { Memenuhi } \\
\text { Kriteria atau } \\
\text { tidak } \\
\text { memenuhi } \\
\text { Kriteria }\end{array}$ \\
\hline
\end{tabular}

Sumber: Penulis, 2021

Setelah terlihat perubahan-dari tahun ke tahun selanjutnya adalah menghitung tren dari masing-masing variabel. Setelah tren dari masing-masing variabel dapat dihitung maka selanjutnya adalah menghitung kriteria keuangan pertama dan kriteria keuangan kedua. Kriteria keuangan pertama adalah kriteria pendapatan non halal yang harus berada di bawah atau sama dengan sepuluh persen. Kriteria keuangan kedua adalah pendanaan non halal yang harus berada di bawah atau sama dengan empat puluh lima persen. Ketika kedua kriteria keuangan ini terpenuhi maka efek tersebut kemungkinan akan masuk ke dalam Daftar Efek Syariah.

Analisa tren merupakan analisa berbasis data, sehingga perlu diingat keterbatasan dari data terutama ketika terjadi perubahan dalam tren. Namun demikian analisa tren tidak hanya berfungsi untuk memberikan sebuah hasil akhir tetapi juga memberikan sebuah sistem peringatan dini. Dalam analisa tren terdapat dua hal yang mempengaruhi yaitu tingkat volatilitas dan tren itu sendiri. Efek yang memiliki volatilitas lebih tinggi akan cenderung memberikan nilai masukan yang berubah dari kuartal ke kuartal. Ini dapat menimbulkan sebuah earnings surprise atau dari sisi pendanaan adalah kenaikan lonjakan tingkat bunga. Efek tipe ini akan lebih rawan keluar dari Daftar Efek Syariah. 
Sebaliknya efek yang cenderung tidak memiliki volatilitas tinggi dapat lebih diramalkan. Dengan memperhatikan posisi terakhir efek ini maka dapat diperkirakan seberapa dekat efek tersebut dengan batasan maksimum yang diizinkan pada kriteria keuangan. Semakin dekat posisi keuangan efek terhadap batasan maksimum semakin mungkin efek tersebut akan keluar dari Daftar Efek Syariah, kecuali ada perubahan tren di periode-periode berikutnya.

Di bawah ada adalah daftar saham dari Indeks Shariah. Terdapat 30 saham yang termasuk dalam indeks shariah. Saham ini berganti tiap 6 bulan sekali. Dari daftar sekarang terdapat empat perusahaan yang keluar dari indeks syariah. Keempat saham tersebut keluar karena tidak lagi memenuhi kriteria dari perusahaan yang masuk daftar indeks shariah.

No. Kode Nama Saham Keterangan

1 ACES Ace Hardware Indonesia Tbk.

2 ADRO Adaro Energy Tbk.

3 AKRA AKR Corporindo Tbk.

4 ANTMAneka Tambang Tbk.

5 ASII Astra International Tbk.

6 BRPT Barito Pacific Tbk.

7 BTPS Bank BTPN Syariah Tbk.

8 CPIN Charoen Pokphand Indonesia Tbk.

9 CTRA Ciputra Development Tbk.

10 ERAA Erajaya Swasembada Tbk.

11 EXCL XL Axiata Tbk.

12 ICBP Indofood CBP Sukses Makmur Tbk.

13 INCO Vale Indonesia Tbk.

14 INDF Indofood Sukses Makmur Tbk.

15 INTP Indocement Tunggal Prakarsa Tbk.

16 JPFA Japfa Comfeed Indonesia Tbk.

17 JSMR Jasa Marga (Persero) Tbk.

18 KLBF Kalbe Farma Tbk.

19 MDKA Merdeka Copper Gold Tbk.

20 MNCN Media Nusantara Citra Tbk.

21 PGAS Perusahaan Gas Negara Tbk.

22 PTBA Bukit Asam Tbk.

23 PWONPakuwon Jati Tbk.

24 SCMA Surya Citra Media Tbk.

25 SMGR Semen Indonesia (Persero) Tbk.

26 TLKM Telekomunikasi Indonesia Tbk.

27 TPIA Chandra Asri Petrochemical Tbk.

28 UNTR United Tractors Tbk.

29 UNVR Unilever Indonesia Tbk.

30 WIKA Wijaya Karya (Persero) Tbk.

Empat saham yang tidak lagi masuk ke dalam daftar Indeks Shariah adalah sahamsaham seperti di bawah ini. 
No. Kode Nama Saham

1 BSDE Bumi Serpong Damai Tbk.

2 ITMG Indo Tambangraya Megah Tbk.

3 LPPF Matahari Department Store Tbk.

4 PTPP PP (Persero) Tbk.

Keempat saham tersebut keluar dari saham indeks shariah. Secara teori ada beberapa penyebab saham dapat keluar dari indeks shariah. Pertama dari sisi kualitatif ketika perusahaan terlibat suatu perkara yang melanggar ketentuan shariah. Kedua adalah aspek kuantitatif. Salah satu aspek kuantitatif adalah faktor pendanaan perusahaan menggunakan komponen utang berbunga yang melebih batasan tertentu.

\begin{tabular}{lrrrrr} 
& 2020 & 2020 & 2019 & 2018 & 2017 \\
\hline Jumlah Liabilitas & 312,339 & 324,576 & 472,945 & 400,524 & 302,362 \\
Jumlah ekuitas & 846,290 & 884,465 & 969,783 & 958,139 & 907,430 \\
Rasio D/E & 0.37 & 0.37 & 0.49 & 0.42 & 0.33 \\
Mean D/E & 0.41 & 0.42 & 0.41 & 0.38 & \\
Standard Deviasi & 0.06 & 0.05 & 0.06 & 0.04 &
\end{tabular}

Tabel 1. Tren Pendanaan Indo Tambangraya Megah

Salah satu contoh dari perubahan pendanaan adalah PT. Indo Tambang Raya Megah. Dalam analisa tren utang berbunga dibandingkan ekuitas maka terlihat bahwa rata-rata bergerak dari utang dibandingkan ekuitas perusahaan adalah di sekitar 41 persen. Padahal porsi utang maksimal adalah $45 \%$. Dengan tingkat standar deviasi rata di kisaran 4 hingga 5 persen maka angka 45 persen akan mudah tercapai. Pada saat penurunan permintaan komoditas yang terjadi d awal pandemi Covid 19 karena penurunan produksi perusahaan manufaktur maka pendapatan perusahaan turun. Turunnya laba perusahaan menurunkan nilai aset perusahaan yang menyebabkan naiknya nilai utang dibandingkan ekuitas.

Sedangkan untuk kedua saham properti yaitu Bumi Serpong Damai dan PT PP adalah perusahaan properti yang merupakan perusahaan siklus dengan permintaan yang elastis. Permintaan dari sebuah perusahaan termasuk ke dalam kategori elastis apabila produk dari perusahaan tersebut memiliki ciri-ciri antara lain: pertama, memiliki harga menengah ke atas. Kedua, produk tersebut akan menghabiskan sebagian besar penghasilan dari konsumen. Ketiga. Harga produk sensitif terhadap faktor eksternal, dalam hal produk properti yaitu suku bunga yang akan menyebabkan naik turunnya cicilan properti.

\begin{tabular}{lrrr} 
& 2019 & 2018 & 2017 \\
\hline Total Kewajiban & $20,897,343$ & $21,814,594$ & $16,754,337$ \\
Total Ekuitas & $33,547,506$ & $30,286,898$ & $29,196,851$ \\
Rasio D/E & 0.62 & 0.72 & 0.57 \\
Uang Muka Diterima & $3,823,018$ & $2,984,663$ & $2,833,479$ \\
Utang Bank & $4,291,279$ & $3,247,272$ & $1,328,772$ \\
Rasio Uang Muka & 0.18 & 0.14 & 0.17 \\
Rasio Utang Bank/Kewajiban & 0.21 & 0.15 & 0.08
\end{tabular}

Tabel 2 Tren Pendanaan Bumi Serpong Damai 
Bumi Serpong Damai memiliki pendanaan baik pendanaan yang bebas bunga maupun pendanaan dengan menggunakan bunga (interest bearing debt). Salah satu sumber dana tanpa bunga adalah uang muka diterima. Ini adalah bentuk pembayaran uang muka dari pembeli rumah ke pengembang. Walaupun bentuk pendanaan ini tanpa bunga tetapi menimbulkan kewajiban bagi pengembang untuk mulai membangun rumah. Ketika pengembang tidak menjalankan kewajibannya maka pengembang akan terancam ingkar janji dan dengan demikian bila di dalam perjanjian terdapat klausul ganti rugi maka pihak pengembang wajib mengeluarkan ganti rugi. Sementara itu penjual juga mengandalkan hutang lainnya untuk mengembang karena pembeli hanya mendanai sebagian dari biaya pembangunan properti. Ketika uang muka menurun dan pinjaman bank mengering maka pengembang akan mengalami penurunan aset sehingga rasio utangnya melebihi rasio utang minimum yang diisyaratkan.

\begin{tabular}{lrrr} 
& 2020 & 2019 & 2018 \\
\hline Penjualan Barang Dagangan & 8,599 & 18,035 & 17,865 \\
Penjualan Eceran Gerai & 3,110 & 6,564 & 6,682 \\
Penjualan Konsinyasi & 5,489 & 11,471 & 11,184 \\
Pertumbuhan Penjualan & 0.48 & 1.01 & \\
Pertumbuhan Eceran & 0.47 & 0.98 & \\
Pertumbuhan Konsinyasi & 0.48 & 1.03 &
\end{tabular}

Tabel 3. Tren Pertumbuhan Penjualan

Sedangkan untuk perusahaan keempat yaitu PT. Matahari yang bergerak di bidang penjualan sandang. Secara industri dengan adanya penjualan daring telah mengikis bisnis PT. Matahari. Penjualan daring membuka peluang bagi berbagai merek pakaian untuk dapat mengakses pembeli. Pukulan yang kedua datang dari kondisi pandemi yang mewajibkan untuk berbagai mal tutup sehingga Matahari juga terpaksa menutup gerainya. Penjualan secara keseluruhan turun lima puluh persen. Penjualan eceran mengalami penurunan lebih dari lima puluh persen dan penjualan konsinyasi juga mengalami penurunan lebih dari lima puluh persen. Pihak yang dahulu melakukan konsinyasi di gerai Matahari kini pun mendiversifikasi penjualannya secara daring.

Dari keempat perusahaan di atas masing-masing memiliki alasan tersendiri yang menjadi penyebab keluarnya dari indeks shariah. Keempatnya sama-sama terpengaruh oleh berbagai faktor turunnya aset yang menyebabkan rasio pendanaannya menjadi tidak memenuhi syarat. Ada satu perusahaan yaitu PT. Matahari yang keluar dari indeks karena perubahan di dalam industri. Namun keluar dari indeks bukan berarti perusahaan ini menjadi tidak dapat menjadi tempat investasi bagi investor. Hanya saja bagi investor yang memegang nilai shariah maka saham-saham ini tidak memenuhi kriteria kuantitatif keuangan. Ke depannya saham-saham ini masih berpeluang untuk masuk kembali ke dalam indeks shariah.

\section{KESIMPULAN}

Penelitian ini berfokus pada meramalkan efek yang akan keluar dari Daftar Efek Syariah. Penelitian ini tidak meramalkan efek yang akan masuk dan menggantikan efek yang keluar. Dengan demikian output pada penelitian ini adalah ramalan posisi efek tersebut pada periode berikutnya. Hal ini akan berguna bagi investor dalam beberapa 
hal. Pertama adalah berguna bagi investor untuk dapat bersiap lebih awal terhadap perubahan efek yang akan terjadi. Kedua harapannya dengan mengetahui posisi ke depannya terutama efek-efek yang berpotensi terdepak dari Daftar Efek Syariah pembuat portofolio dapat membuat portofolio yang tidak terdiri dari efek-efek tersebut.

Ke depannya dapat dilakukan penelitian dengan menggunakan metode peramalan yang lainnya. Peramalan dengan menggunakan analisa tren digunakan karena metode ini sederhana dengan sedikit asumsi. Jadi peramalan dilakukan dengan mengandalkan data yang ada di masa lalu. Kelemahan dari pendekatan ini adalah pola data di masa depan dapat berubah dari data di masa lalu.

\section{SARAN}

Ke depannya dapat dilakukan penelitian dengan menggunakan metode peramalan yang lainnya. Peramalan dengan menggunakan analisa tren digunakan karena metode ini sederhana dengan sedikit asumsi. Jadi peramalan dilakukan dengan mengandalkan data yang ada di masa lalu. Kelemahan dari pendekatan ini adalah pola data di masa depan dapat berubah dari data di masa lalu.

\section{DAFTAR PUSTAKA}

Agustin, P., \& Mawardi, I. (2014). Perilaku Investor Muslim dalam Bertransaksi Saham di Pasar Modal. Jurnal Ekonomi Syariah Teori dan Terapan, 1(12).

Antill, S., \& Grenadier, S. R. (2019). Optimal capital structure and bankruptcy choice: Dynamic bargaining versus liquidation. Journal of Financial Economics, 133(1), 198-224.

Asytuti, R. (2017). The Impact of Religiousity to Preferences of Muslim 'S Investor in Capital Market. JURNAL HUKUM ISLAM, 115-133.

Baining, M. E., \& Aryani, L. (2021). PROFITABILITAS PADA PERUSAHAAN SYARIAH DI DAFTAR EFEK SYARIAH. J-ISCAN: Journal of Islamic Accounting Research, 3(1), 59-76.

Hartati, N. (2021). Investasi Saham Syariah di Bursa Efek Indonesia dalam Perspektif Hukum Ekonomi Syariah. Jurnal Hukum Ekonomi Syariah, 5(01), 31-48.

Nan, L. (2019). On the Financing Regulation of Stock Market and the Optimal Capital Structure of Listed Companies. The Frontiers of Society, Science and Technology, 1(7).

Primadhanny, R. (2016). Pengaruh struktur kepemilikan terhadap struktur modal pada perusahaan sektor pertambangan yang tercatat di bei periode 2010-2014. Jurnal Ilmu Manajemen (JIM), 4(3).

Romi Gunawan, R. (2021). Faktor-Faktor yang Mempengaruhi Tingkat Sewa Sukuk Ijarah Pada Perusahaan Yang Terdaftar di Daftar Efek Syariah Periode 20142019 (Doctoral dissertation, Universitas Islam Negeri Sultan Syarif Kasim Riau). 
AKSARA: Jurnal Ilmu Pendidikan Nonformal

P-ISSN 2407-8018 E-ISSN 2721-7310 DOI prefix 10.37905

Volume 08, (1), January 2022

http://ejurnal.pps.ung.ac.id/index.php/Aksara 